\title{
Yield and development of mung bean according to the plant density
}

\section{Edvan da Costa Silva ${ }^{1}$, Nei Peixoto ${ }^{2}$, Natália Arruda $^{3}$, Natália Cássia de Faria Ferreira ${ }^{2}$, Luís Augusto Batista de Oliveira ${ }^{2}$}

${ }^{1}$ Universidade Estadual do Oeste do Paraná, Campus Marechal Cândido Rondon, Marechal Cândido Rondon, Paraná, Brasil. E-mail: edvan_costa@outlook.com. Parte da dissertação de mestrado do primeiro autor.

${ }^{2}$ Universidade Estadual de Goiás, Campus Ipameri, Ipameri, Goiás, Brasil. E-mail: nei.peixoto48@gmail.com, natcassiadefaria@gmail.com, luisaugusto-1993@hotmail.com

${ }^{3}$ Universidade Estadual de Maringá, Campus Regional de Umuarama, Umuarama, Paraná, Brasil. E-mail: nathy.a@ hotmail.com

Received: 24/05/2019; Accepted: 16/09/2019.

\section{ABSTRACT}

The study aimed to determine the optimal population density for mung bean crop by defining row spacing, and number of plants per meter. The experimental design was a randomized block with treatments arranged in a splitplot scheme with four replications. Two row spacings $(25$ and $50 \mathrm{~cm}$ ) were allocated in the plots, and six number of plants per meter $(4,8,12,16,20$, and 24 plants) were allocated in the subplots. The experimental units had $4.0 \mathrm{~m}$ long, and $2.5 \mathrm{~m}$ wide, with $4.0 \mathrm{~m}^{2}$ of useful area. In the useful area of plot, plant height, stem diameter, number of pods per plot, pod length, pod width, number of grains per pod, 100-pods weight, 100-grains weight, final plant population, and grain yield were evaluated. Plant height, pod length, pod width, number of grains per pod, and 100pod weight were not influenced by row spacing and number of plants per meter. There was influence of significant interaction between the factors studied on 100-grains weight and final plant population. There was a significant effect only of number of plants per meter on stem diameter, number of pods per plot, and grain yield. The row spacing of $50 \mathrm{~cm}$ and 24 plants per meter increased mung bean grain yield, revealing itself as a strategy of gain in the grain yield of the crop.

Keywords: Spacing, Grain yield, Vigna radiata.

\section{Produção e desenvolvimento de feijão mungo em função de densidade populacional de plantas}

\section{RESUMO}

Esse trabalho teve como objetivo determinar a melhor densidade populacional de plantas para a cultura do feijão mungo, por meio da definição de espaçamento entre fileiras e número de plantas por metro linear. O delineamento experimental utilizado foi o de blocos casualisados com os tratamentos dispostos em parcelas subdivididas, tendo, nas parcelas, dois espaçamentos entre fileiras $(25 \mathrm{e} 50 \mathrm{~cm})$ e, nas subparcelas, seis números de plantas por metro linear $(4,8,12,16,20$ e 24 plantas), com quatro repetições. As unidades experimentais possuíram as seguintes dimensões: 4,0 $\mathrm{m}$ de comprimento e 2,5 de largura, tendo área útil de $4 \mathrm{~m}^{2}$. Na parcela útil, avaliaram-se altura de planta, diâmetro do caule, número de vagens por parcela, comprimento de vagem, largura de vagem, número de sementes por vagem, massa de 100 vagens, massa de 100 sementes, estande final de plantas e produtividade. Os resultados da análise de variância, da altura de planta, do comprimento de vagem e largura de vagem, do número de sementes por vagem e massa de 100 vagens não foram influenciados pelos espaçamentos entre linhas e números de plantas por metro linear. Para a massa de 100 sementes e estande final de plantas, houve interação significativa entre os fatores estudados. Para os dados de diâmetro do caule, número de vagens por parcela e produtividade, houve efeito significativo isolado apenas para os números de plantas por metro linear. O espaçamento de $50 \mathrm{~cm}$ entre fileiras e 24 plantas por metro linear incrementa a produtividade do feijão mungo, revelando-se como uma estratégia de ganhos na produção da espécie.

Palavras-chave: Espaçamento, Rendimento de grãos, Vigna radiata. 


\section{Introduction}

Legumes are the main source of protein for human consumption, characterized by the richness in minerals and vitamins (Choudhary et al., 2017). Between the highest-yielding legumes in the world, stands out mung bean (Vigna radiata L. Wilczek), native from Asia, is cultivated across the continent, with emphasis on India (Somta et al., 2014; Zhang et al., 2013).

Mung beans have two planting seasons due to their short cycle (Pratap et al., 2014). Its short growing period allows it to adapt to many cropping systems, which become easily adjusted at crop rotations, providing diversification in cropping systems. The species can be adopted in many production systems because besides increasing the income of small farmers, it provides significant improvements in soil fertility. Given its short growing period, low production cost, and adaptability in a wide range of soil and climate conditions, the growth of this crop is favored in different regions (Pratap et al., 2013).

Legume producers have been showing increasing interest in mung bean growth, which highlights a new alternative to agricultural production. $V$. radiata is known as a healthy and inexpensive source of protein in combination with essential amino acids, particularly lysine, among other compounds such as minerals and vitamins (Saini et al., 2010).

The reasons for low yield are multiple, related to management, varieties, and inadequate agronomic management. Knowing these challenges faced by legume producers, it is necessary to invest in alternatives to maximize yield per unit area by applying appropriate technologies and management practices to the cultivation of the species, with the amount of seed per meter being an important component. As there are large differences in yield between the cultivars of mung beans (Mondal et al., 2011), the maximum potential can be achieved by adopting the correct row spacing for each cultivar (Ahmed et al., 2011).

The sowing density of mung beans may ensure the optimal plant population as well as increase grain yield (Albayrak et al., 2011). For most crops, plant density has a major influence on biomass and grain yield, and profitability (Ciampitti and Vyn, 2011). According to Begum et al. (2009), the yield of mung bean decreases as the population density increases, however, the increase in the number of pods per plant occurs according to the reduction of population density, and the potential yield of the mung bean cultivars is approximately $1.5-2.5 \mathrm{t} \mathrm{ha}^{-1}$.

Generally, grain yield increases as population density increase up to the upper limit. The highest grain yield in Punjab, India, was achieved with the population density equivalent to 40 plants $\mathrm{m}^{-2}$, with a spacing of
$25 \times 10 \mathrm{~cm}$ (Singh et al., 2011); in Taiwan, with the population density of 20 plants $\mathrm{m}^{-2}$, and a spacing of $50 \times 10 \mathrm{~cm}$; in Bangladesh with 30 plants $\mathrm{m}^{-2}$ (Hossain et al., 2011), and in Iran with 25 plants $\mathrm{m}^{-2}$ (Rafiei, 2009).

Based on the growing market demand to produce mung bean in Brazil, its adoption in production systems is even more prominent, in which mung beans are a viable and profitable alternative for small producers. In this context, information on the growth of this crop will serve as a guide for farmers wishing to start the mung bean production process.

Given this problem, this study aimed to determine the best population density for the mung bean (Vigna radiata) crop by defining the optimal row spacing, and number of plants per meter.

\section{Material and Methods}

The experiment was carried out at Goiás State University, Ipameri Campus. The coordinates of the campus are $17^{\circ} 42^{\prime} 41.73^{\prime \prime} \mathrm{S}$, and $48^{\circ} 8^{\prime}$ 20.29" O. According to the Koppen classification, the climate of the region is tropical (Aw) with two well-defined seasons, dry winter and rainy summer, with periods of drought during the rainy season (summer). The average air temperature in all months of the year is above $18{ }^{\circ} \mathrm{C}$. The soil of the experimental area is classified as Latossolo Vermelho-Amarelo distrófico (Santos et al., 2013), or Oxisol (Soil Survey Staff, 2014).

The chemical properties of $0-20 \mathrm{~cm}$ soil layer was: $\mathrm{pH}$ in $\mathrm{CaCl}_{2}=4.91$; Available $\mathrm{P}$ (Mehlich 1 extractor $)=$ $8.6 \mathrm{mg} \mathrm{dm}^{-3}$; Available $\mathrm{K}=0.3 \mathrm{cmol}_{\mathrm{c}} \mathrm{dm}^{-3} ; \mathrm{Ca}=1.7$ $\mathrm{cmol}_{\mathrm{c}} \mathrm{dm}^{-3} ; \mathrm{Mg}=1.0 \mathrm{cmol}_{\mathrm{c}} \mathrm{dm}^{-3} ; \mathrm{Al}=0.0 \mathrm{cmol}_{\mathrm{c}} \mathrm{dm}^{-3}$; $\mathrm{H}+\mathrm{Al}, 4.0 \mathrm{cmol}_{\mathrm{c}} \mathrm{dm}^{-3}$; CTC $7.06 \mathrm{cmol}_{\mathrm{c}} \mathrm{dm}^{-3}$; and base saturation of $43.0 \%$.

Data about rainfall $(\mathrm{mm})$ and average temperature $\left({ }^{\circ} \mathrm{C}\right)$ during the experiment conduction are shown in Figures 1 and 2. The cultivar MGS Esmeralda of mung bean was used to test its adaptation to the edaphoclimatic conditions of the region. The experimental design was a randomized block with treatments arranged in a split-plot scheme with four replications. Two row spacings $(25$ and $50 \mathrm{~cm}$ ) were allocated in the plots, and six number of plants per meter $(4,8,12,16,20$, and 24 plants) were allocated in the subplots.

The experimental units had $4.0 \mathrm{~m}$ long, and $2.5 \mathrm{~m}$ wide, with $4.0 \mathrm{~m}^{2}$ of useful area. Plots with $50 \mathrm{~cm}$ row spacing were composed of four rows, the two central ones being considered as useful area and the two lateral ones as borders. Plots with $25 \mathrm{~cm}$ row spacing consisted of eight rows, the four central rows were considered as useful area and the two lateral rows of each side as borders. 


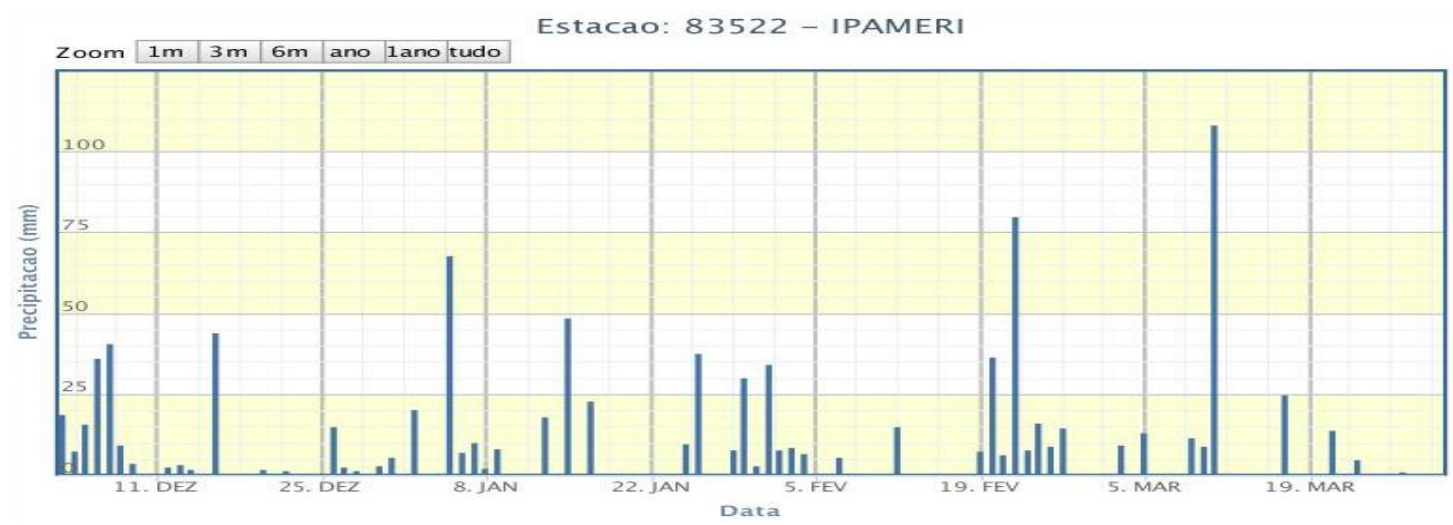

Figure 1. Rainfall (mm) during the experiment conduction, from December 2017 to March 2018. Source: INMET, 2018.

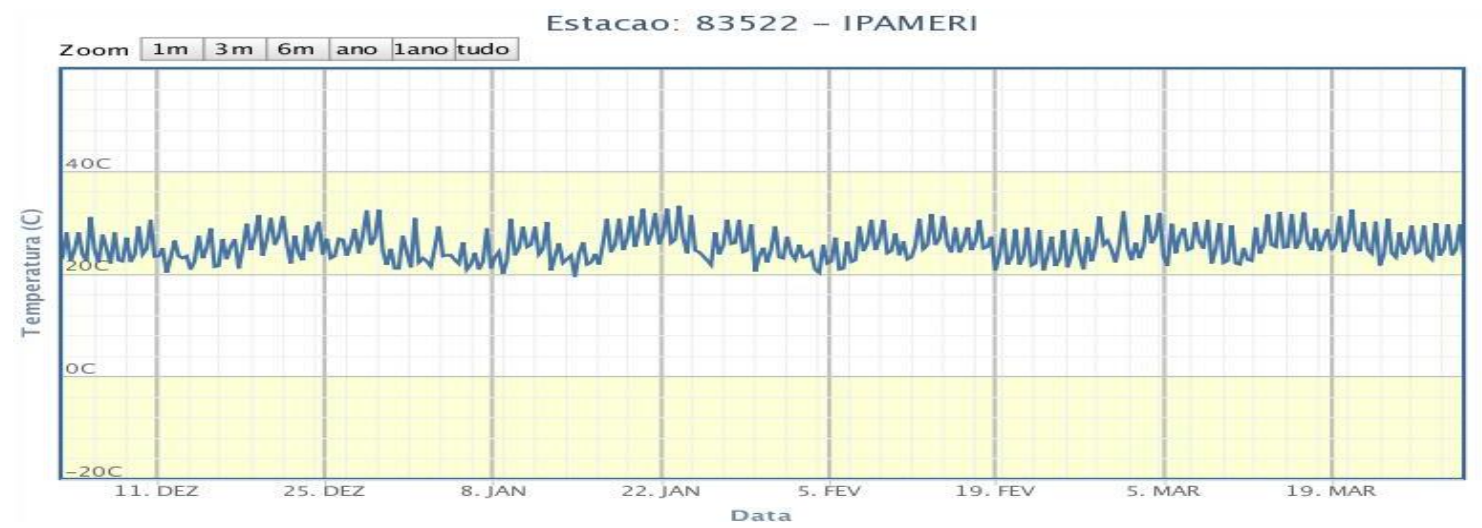

Figure 2. Average temperature $\left({ }^{\circ} \mathrm{C}\right)$ during the experiment conduction, from December 2017 to March 2018. Source: INMET, 2018.

The sowing was done on December 15, 2017. Sowing was done with $50 \%$ more seeds for each density to ensure the desired plant density. On the tenth day, the adjust of densities was done. Rows were demarcated with a tractor, and the seeds were manually sown at 4 $\mathrm{cm}$ depth. At sowing, $600 \mathrm{~kg} \mathrm{ha}^{-1}$ of the formulated fertilizer 5-25-15 were manually applied, and at 20 DAE (days after emergence), $150 \mathrm{~kg} \mathrm{ha}^{-1}$ of urea was applied. Weed control was done weekly through manual weeding. Two harvests were carried out, the first on February 23, 2018, and the second on March 10, 2018, both manually, removing the mature pods from the plants, placing them in paper bags, and leaving them in a ventilated place to drying for two days.

The following characters were evaluated: a) plant height: determined in 10 plants of the useful area of each plot, using a measuring tape, and the result expressed in centimeters (cm); b) stem diameter: determined in 10 plants in the useful area of each plot, using a digital caliper, expressed in millimeters; c) number of pods per plot: all the pods present in the useful area of each plot were quantified; d) pod length: determined in 10 pods randomly collected from plants in the useful area of each plot, using a $30 \mathrm{~cm}$ graduated ruler, with the result expressed in centimeters $(\mathrm{cm})$; e) pod width: determined from 10 pods randomly taken from plants in the useful area of each plot using a digital caliper, with the data expressed in millimeters; f) number of seeds per pod: determined from 10 pods harvested at random from plants present in the useful area of each plot; g) 100 pod mass: 100 pods were randomly collected from the plants present in the useful area of each plot, and a precision scale was used to determine the mass, the result being expressed in grams; h) 100-grain weight: obtained randomly from the useful area of each plot, and they were weighed on a precision scale, with the result expressed in grams; i) grain yield: was obtained with the mass of grains produced in the useful area of each plot, extrapolating this value to $\mathrm{kg}$ $\mathrm{ha}^{-1}$.

Data were subjected to variance analysis separately and means compared by Tukey test at $5 \%$ probability for row spacings. For the means from the number of plants per meter, were adjusted equations through regression analysis. Statistical analysis was processed using Sisvar software (Ferreira, 2011).

\section{Results and Discussion}

There was a significant effect only of number of plants per meter on stem diameter (STD) and number of pods per plot (NPP). Plant height (PLH), pod length (PDL), and pod width (PDW) were not influenced by row spacing and number of plants per meter (Table 1). 
Table 1. Average results of plant height (PLH), stem diameter (STD), number of pods per plot (NPP), pod length (PDL), and pod width (PDW), produced according to row spacing and number of plants per meter. Ipameri-GO, 2019.

\begin{tabular}{|c|c|c|c|c|c|}
\hline \multirow{2}{*}{ Treatments } & PLH & STD & NPP & PDL & PDW \\
\hline & $(\mathrm{cm})$ & $(\mathrm{mm})$ & - & $(\mathrm{cm})$ & $(\mathrm{mm})$ \\
\hline \multicolumn{6}{|l|}{ Row spacing (S) } \\
\hline $25 \mathrm{~cm}$ & $64.68 \mathrm{a}$ & $6.24 \mathrm{a}$ & $1017.54 \mathrm{a}$ & $8.87 \mathrm{a}$ & $5.49 \mathrm{a}$ \\
\hline $50 \mathrm{~cm}$ & $60.07 \mathrm{a}$ & $7.06 \mathrm{a}$ & $907.50 \mathrm{a}$ & $9.05 \mathrm{a}$ & $5.31 \mathrm{a}$ \\
\hline \multicolumn{6}{|c|}{$\mathrm{N}^{0}$ of plants $\mathrm{m}^{-1}(\mathrm{~N})$} \\
\hline 4 & 60.66 & (2) & (2) & 9.02 & 5.52 \\
\hline 8 & 59.20 & -- & -- & 8.84 & 5.41 \\
\hline 12 & 64.55 & --- & --- & 8.92 & 5.32 \\
\hline 16 & 64.50 & --- & --- & 9.00 & 5.33 \\
\hline 20 & 62.23 & --- & --- & 9.03 & 5.55 \\
\hline 24 & 62.83 & --- & --- & 8.97 & 5.41 \\
\hline \multicolumn{6}{|c|}{ F-values } \\
\hline $\mathbf{S}$ & $4.26^{\mathrm{ns}}$ & $9.61^{\mathrm{ns}}$ & $0.78^{\mathrm{ns}}$ & $8.07^{\mathrm{ns}}$ & $0.73^{\mathrm{ns}}$ \\
\hline $\mathbf{N}$ & $0.65^{\mathrm{ns}}$ & $3.92 * *$ & $4.95 * *$ & $0.16^{\mathrm{ns}}$ & $0.80^{\mathrm{ns}}$ \\
\hline $\mathbf{S} \times \mathbf{N}$ & $1.60^{\mathrm{ns}}$ & $2.36^{\mathrm{ns}}$ & $0.49^{\mathrm{ns}}$ & $2.48^{\mathrm{ns}}$ & $2.08^{\mathrm{ns}}$ \\
\hline CV (\%) & 12.15 & 13.17 & 22.22 & 2.44 & 12.78 \\
\hline
\end{tabular}

Means followed by the same lowercase letter in the column for each studied factor do not differ from each other by the Tukey test at $5 \%$ probability. ${ }^{* *}=$ Significant at $1 \%$ probability; $\mathrm{ns}=$ not significant $;(2)=$ Significant regression for effect of number of plants per meter.

For the stem diameter values, the decreasing linear equation was adjusted (Figure 3). Stem diameter values ranged from $6.16 \mathrm{~mm}$ with 24 plants $\mathrm{m}^{-1}$ to $7.17 \mathrm{~mm}$ with 4 plants $\mathrm{m}^{-1}$, that is, the stem diameter values with 24 plants $\mathrm{m}^{-1}$ was $16.49 \%$ smaller than the diameter recorded for 4 plants $\mathrm{m}^{-1}$.

The reduction in stem diameter intensified as the population density increased, a fact due to intraspecific competition, showing that increases in population density cause a reduction in stem diameter. Significant reductions in stem diameter as a result of increases in population density may cause plant lodging, interfering directly at the epicotyl region, which consequently impairs yield (Bezerra et al., 2012).

For the number of pods per plot values, an increasing linear equation was adjusted (Figure 4), reaching the highest result $\left(1,137\right.$ pods plot $\left.^{-1}\right)$ with 24 plants $\mathrm{m}^{-1}, 44.22 \%$ higher than the number of pods per plot registered for 4 plants $\mathrm{m}^{-1}$ (788 pods plot $^{-1}$ ).

Singh et al. (2011), evaluating different mung bean genotypes at different planting densities in different

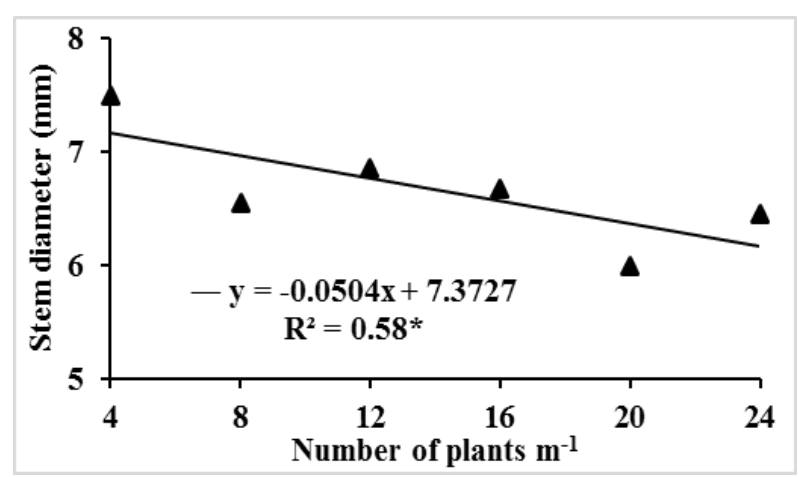

Figure 3. Stem diameter of mung bean plants according to the row spacing and number of plants per meter. Ipameri-GO, 2019. environments, observed that the number of pods per plant was significantly higher at the density of 33 plants $\mathrm{m}^{-2}$ than 40 and 50 plants $\mathrm{m}^{-2}$ for the two environments (Ludhiana and Taiwan) and in the two crop seasons, 2002 and 2003.

The increased competition caused in the denser populations has a direct effect on the yield capacity of the plants. Mendes et al. (2005) reported that, in high populations, there is a direct effect on the yield capacity of the plant through a decreasing number of inflorescences and flowers per plant. Several authors claim that the number of pods per plant is the yield component most affected by increasing plant density (Naim and Jabereldar, 2010; Bezerra et al., 2012; Oliveira et al., 2015). Probably, the reductions in species development can be explained by the fact that the higher population density, the lower light interception caused by plant overlap, where decreases in photosynthetic potential cause a reduction in carbon assimilation, reflecting directly on lower plant development and yield (Oliveira et al., 2015).

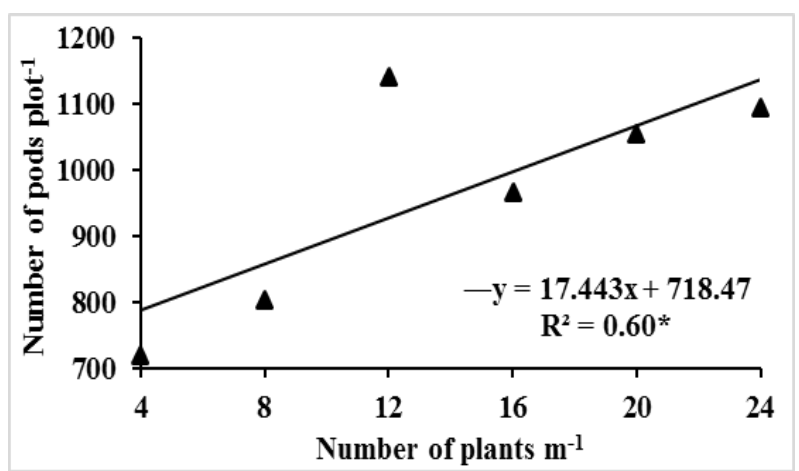

Figure 4. Number of pods per plot of mung bean plants according to the row spacing and number of plants per meter. Ipameri-GO, 2019. 
Bezerra et al. (2009), working with cowpea beans, found that different plant populations have a significant effect on the number of pods per plant, and that increasing population density from 100,000 to 300,000 plants $\mathrm{ha}^{-1}$ reduced the number of pods per plant by $63 \%$. Increases in the spatial arrangement of plants promote a considerable reduction in the number of pods per plant, since they cause greater intraspecific competition in denser populations, and thus interfere in plant production capacity (Camara et al., 2018).

There was significant interaction between row spacing and number of plants per meter for the 100grain weight (W100) and the final plant population (FPP) (Table 2). There was significant effect only of number of plants per meter on grain yield (GRY), while, there was no influence of row spacing and number of plants per meter on number of grains per pod (NGP) and 100-pod weight (P100) (Table 2).

Row spacing had significantly influenced on 100grains weight. The $50 \mathrm{~cm}$ row spacing had a significantly higher average $(5.87 \mathrm{~g})$ than $25 \mathrm{~cm}$ row spacing $(5.71 \mathrm{~g}$ ) (Table 2). For the 100-grains weight means, a quadratic equation was adjusted for number of plants per meter at the $25 \mathrm{~cm}$ row spacing. The 100grains weight increased up to $5.93 \mathrm{~g}$, with 22.15 plants $\mathrm{m}^{-1}$ (Figure 5). About the 100-grains weight at $50 \mathrm{~cm}$ row spacing, a quadratic equation was adjusted for the number of plants per meter (Figure 5). A decrease of 100 -grains weight up to $5.78 \mathrm{~g}$, with 21.78 plants $\mathrm{m}^{-1}$, was observed. There was an increase in grain yield of the species at the $25 \mathrm{~cm}$ row spacing. Probably this increase occurred due to the efficient use of solar energy utilization, which, with the increase of the population density, was better distributed on the leaves, resulting in a higher concentration of assimilates in the grains.

Bezerra et al. (2008) report that higher population density tends to have smaller 1000-grains weight, due to competition between plants, thus favoring a lower translocation of photoassimilates to the grains, resulting in less dry matter accumulation.

Results from Bezerra et al. (2008) corroborate those found by Nunes et al. (2017), who, using the row spacing of $50 \mathrm{~cm}$ and evaluating different densities of cowpea plants, found that increasing plant density increases grain weight.

The results observed in the present study differ from those found by Santos (2013), who, by evaluating the effects of plant density on grain yield and its components of cowpea under rainfed condition, found that as the amount increased of plants per hectare, there was a decrease in seed weight.

Grain weight is a variable of high importance since it is generally used to calculate sowing density and to evaluate seed quality, maturity, and health (Brasil, 2009). Therefore, this increase in grain weight in response to the increase in population density becomes interesting because it is a characteristic related to its vigor. For the mung bean yield data, an increasing linear equation was adjusted (Figure 6), reaching a maximum grain yield of $1,296.54 \mathrm{~kg} \mathrm{ha}^{-1}$, with 24 plants $\mathrm{m}^{-1}$, $41.71 \%$ higher than recorded for 4 plants $\mathrm{m}^{-1}(914.90 \mathrm{~kg}$ ha $^{-1}$ ) (Table 2).

Table 2. Average results of number of grains per pod (NGP), 100-pods weight (P100), 100-grains weight (W100), final plant population (FPP), and grain yield (GRY) of mung bean, produced according to row spacing and number of plants per meter. IpameriGO, 2019.

\begin{tabular}{|c|c|c|c|c|}
\hline \multirow{2}{*}{ Treatments } & NGP & $\mathbf{P 1 0 0}$ & W100 & GRY \\
\hline & - & $(\mathrm{g})$ & $(\mathrm{g})$ & $\left(\mathrm{kg} \mathrm{ha}^{-1}\right)$ \\
\hline \multicolumn{5}{|c|}{ Row spacing (S) } \\
\hline $25 \mathrm{~cm}$ & $10.21 \mathrm{a}$ & $76.39 \mathrm{a}$ & $5.71 \mathrm{~b}$ & $1128.04 \mathrm{a}$ \\
\hline $50 \mathrm{~cm}$ & $10.25 \mathrm{a}$ & $80.76 \mathrm{a}$ & $5.87 \mathrm{a}$ & $1083.40 \mathrm{a}$ \\
\hline \multicolumn{5}{|c|}{$\mathrm{N}^{0}$ of plants $\mathrm{m}^{-1}(\mathrm{~N})$} \\
\hline & 10.75 & 78.90 & (1) & (2) \\
\hline 4 & 9.75 & 81.58 & --- & --- \\
\hline 8 & 10.25 & 78.83 & --- & --- \\
\hline 12 & 10.00 & 78.38 & --- & --- \\
\hline 16 & 10.13 & 76.28 & --- & --- \\
\hline 20 & 10.50 & 77.49 & --- & --- \\
\hline \multicolumn{5}{|c|}{ F-values } \\
\hline $\mathbf{S}$ & $0.03^{\mathrm{ns}}$ & $9.34^{\mathrm{ns}}$ & $188.70 * *$ & $0.05 \mathrm{~ns}$ \\
\hline $\mathbf{N}$ & $1.01^{\mathrm{ns}}$ & $1.24^{\mathrm{ns}}$ & $45.65 * *$ & $3.29 *$ \\
\hline $\mathbf{S} \times \mathbf{N}$ & $0.32^{\mathrm{ns}}$ & $1.37^{\mathrm{ns}}$ & $205.611 * *$ & $0.36^{\mathrm{ns}}$ \\
\hline $\mathrm{CV}(\%)$ & 7.77 & 6.31 & 0.72 & 26.37 \\
\hline
\end{tabular}

Means followed by the same lowercase letter in the column for each studied factor do not differ from each other by the Tukey test at $5 \%$ probability. $* *=$ Significant at $1 \%$ probability; $*=$ Significant at $5 \%$ probability; ns = not significant; (1) Significant regression for row spacing and number of plants per meter; $(2)=$ Significant regression for the effect of number of plants per meter. 


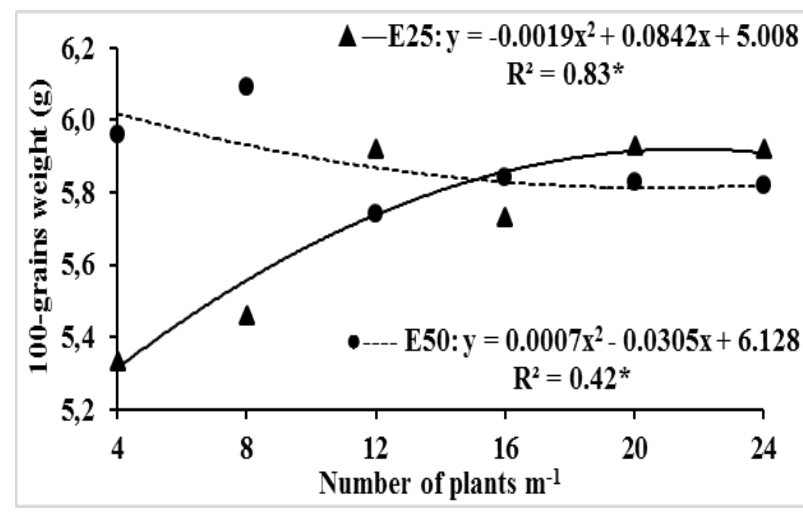

Figure 5. 100-grains weight of mung bean plants according to the row spacing and number of plants per meter. Ipameri-GO, 2019.

Results found in the present study corroborate those obtained by Nunes et al. (2017), who evaluated the effects of molybdenum doses and population densities on cowpea grain yield, cultivar BRS Novaera. The authors verified that grain yield had a linear increase due to the increase of plant population per hectare. Similar results were also found by Bezerra et al. (2009) for cowpea lineage IT87D6113, in which the increase in plant densities $(100,200,300,400$, and 500 thousand plants $\mathrm{ha}^{-1}$ ) increased grain yield. Increases in grain yield in response to increasing population density have also been reported by Njoku and Muoneke (2008); Naim and Jabereldar (2010).

Grain yield is the result of several physiological, biochemical, phenological, and morphological events that occur in the plant system. The lower grain yield in the treatments with low number of plants per meter may be due to a substandard plant population (Mansoor et al., 2010).

Different results were approached by Bezerra et al. (2014), where they concluded that in cowpea cultivar BRS Novaera, the increase in plant population (100, 200, 300, 400, and 500 thousand plants $\mathrm{ha}^{-1}$ ) provided a decrease in grain yield per plant and grain yield. Contrary results were also found by Bezerra et al. (2012), observing decreases in grain yield in response to the increase in the density of cowpea plants $(100,200$, 300,400 , and 500 thousand plants $\mathrm{ha}^{-1}$ ) of cultivar BRS Guariba cultivar.

Under the conditions studied, to produce mung bean, the $50 \mathrm{~cm}$ row spacing with 24 plants per meter had the best results, evidenced by the higher number of pods per plot, final plant population, and grain yield.

The knowledge of the responses of the mung bean plant concerning to row spacing and number of plants per meter becomes essential for the evaluation and recommendation of proper management aiming to obtain maximum yield potential of the crop, since there is still little information found in the literature about it, needing further studies.

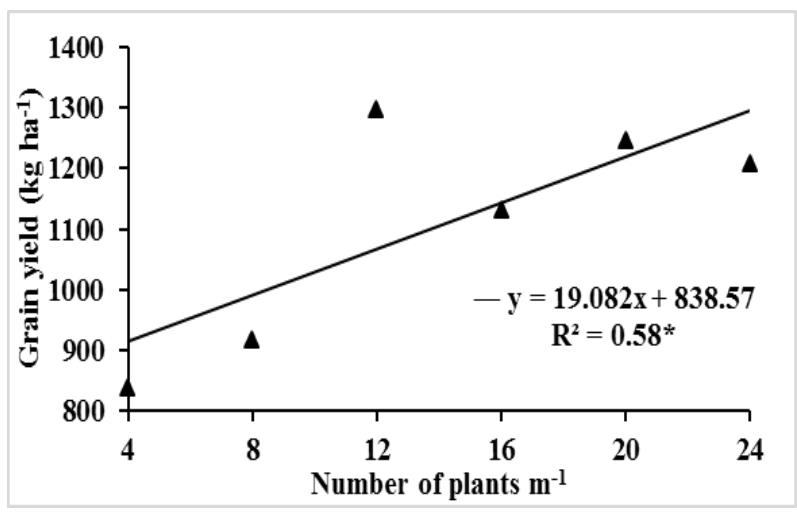

Figure 6. Grain yield of mung bean plants according to the row spacing and number of plants per meter. Ipameri-GO, 2019.

\section{Conclusions}

The row spacing of $50 \mathrm{~cm}$, and 24 plants per meter increased mung bean grain yield, revealing itself as a strategy of gain in the grain yield of the crop.

\section{Acknowledgments}

The authors wish to thank the Coordination for the Improvement of Higher Level Personnel (CAPES) for their support and for the master's scholarship.

\section{Bibliographic References}

Ahmed, K.U., Nahar, K., Rahmatullah, N.M., Faruq, G., Alamgir, M.D.A., 2011. Yield components and yield of different mungbean varieties as affected by row spacing. American-Eurasian Journal of Agronomy, 4(1), 1-5.

Albayrak, S., Türk, M., Yüksel, O., 2011. Effect of row spacing and seeding rate on hungarian vetch yield and quality. Turkish Journal of Field Crops, 16(1), 54-58.

Begum, M.S.T.N., M. Begum, M.P.A., Juraimi, A.S., 2009. Otimizing Seed Rate for Summer Mungbean Varieties. Journal of Agriculture Social \& Sciences, 5(4), 114-118.

Bezerra, A.A.C., Alcântara Neto, F., Neves, A.C., Maggioni, K., 2012. Comportamento morfoagronômico de feijão-caupi, cv. BRS Guariba, sob diferentes densidades de plantas. Revista Ciências Agrárias, 55, (3), 184-189.

Bezerra, A.A.C., Neves, A.C., Alcântara Neto, F., Silva Júnior, J.V., 2014. Morfofisiologia e produção de feijão-caupi, cultivar BRS Novaera, em função da densidade de plantas. Revista Caatinga, 27(4), 135-141.

Bezerra, A.A.C., Távora, F.J.A.F., Freire Filho, F.R., Ribeiro, V.Q., 2009. Características de dossel e de rendimento em feijão-caupi ereto em diferentes densidades populacionais. Pesquisa Agropecuária Brasileira, 44(10), 1239-1245.

Bezerra, A.A.C., Távora, F.J.A.F., Freire Filho, F.R., Ribeiro, V.Q., 2008. Morfologia e produção de grãos em linhagens modernas de feijão-caupi submetidas a diferentes densidades populacionais. Revista de Biologia e Ciência da Terra, 8(5), 85-93. 
Brasil. Ministério da Agricultura, Pecuária e Abastecimento, 2009. Regras para análise de sementes. Ministério da Agricultura, Pecuária e Abastecimento. Secretaria de Defesa Agropecuária. Brasília, DF: Mapa/ACS, 395 p.

Camara, F.T., Mota, A.M.D., Nicolau, F.E.A., Pinto, A.A., Silva, J.M.F., 2018. Produtividade de feijão caupi crioulo em função do espaçamento entre linhas e número de plantas por cova. Revista de Agricultura Neotropical, 5(2), 19-24.

Choudhary, M., Jat, H.L., Bijarniya, S.; Bhati, V., 2017. Adoption of mungbean production technology by the farmers in Jaipur district of Rajasthan, India. International Journal of Current Microbiology and Applied Sciences, 6(4), 739-743.

Ciampitti, I.A., Vyn, T.J., 2011. A comprehensive study of plant density consequences on nitrogen uptake dynamics of maize plants from vegetative to reproductive stages. Field Crop Research, 121(1), 2-18.

Ferreira, D.F., 2011. Sisvar: a computer statistical analysis system. Ciência e Agrotecnologia, 35(6), 1039-1042.

Hossain, M.K., Ali, M.H., Uddin, A.F.M.J., 2011. Influence of plant population on growth and yield of summer mungbean (Vigna radiata). Bangladesh Research Publications Journal, 6(2), 167-173.

INMET, Instituto Nacional de Meteorologia, 2018. Estações Convencionais - Gráficos. http://www.inmet.gov.br/portal/index.php?r=h_estacoes_conv _graf (acessado 23 de agosto de 2018).

Mansoor, M., Khan, H., Ayaz, M., Zubair, M., Nadim, M.A., 2010. Effect of different planting densities on some physiological parameters of mungbean. Journal of Research, 26(2), 1-8.

Mendes, R.M.S., Távora, F.J.A.F., Pinho, J.L.N., Pitombeira, J.B., 2005. Alterações na relação fonte-dreno em feijão-decorda submetido a diferentes densidades de plantas. Revista Ciência Agronômica, 36(1), 82-90.

Mondal, M.M.A., Hakim, M.A., Juraimi, A.S., Azad, M.A.K., Karim, M.R., 2011. Contribution of morphophysiological attributes in determining the yield of mungbean. African Journal of Biotechnology, 10(60), 12897-12904.

Naim, A.M., Jabereldar, A.A., 2010. Effect of Plant density and Cultivar on Growth and Yield of Cowpea (Vigna unguiculata L.Walp). Australian Journal of Basic and Applied Sciences, 4(8), 3148-3153.

Njoku, D.N., Muoneke, C.O., 2008. Effect of cowpea planting density on growth, yield and productivity of component crops in cowpea/cassava intercropping system. Journal of Tropical Agriculture, Food, Environment and Extension, 7(2), 106-113.
Nunes, R.T., Souza, U. O., Araujo Neto, A., Morais, O.M., Fogaça, J.J.N.L., Santos, J.L., Cardoso, A.D., São José, A.R. 2017. Produção e qualidade de sementes de feijão-caupi em função de doses de molibdénio e da população de plantas. Revista de Ciências Agrárias, 40(3), 533-542.

Oliveira, S.R.M., Andrade Júnior, A.S., Ribeiro, V.Q., Brito, R.R., Carvalho, M.W., 2015. Interação de níveis de água e densidade de plantas no crescimento e produtividade do feijão-caupi, em Teresina, PI. Irriga, 20(3), 502-513.

Pratap, A., Basu, P.S., Gupta, S., Malviya, N., Rajan, N., Tomar, R., Madhavan, L., Nadarajan, N., Singh, N.P., 2014. Identification and characterization of sources for photo- and thermo-insensitivity in Vigna species. Plant Breeding, 133(6), 756-764.

Pratap, A., Gupta, D.S., Singh, B.B., Kumar, S., 2013. Development of super early genotypes in Mungbean [Vigna radiata (L.) Wilczek]. Legume Research, 36(2), 105-110.

Rafiei, M., 2009. Influence of tillage and plant density on mungbean. American-Eura-sian Journal of Sustainable Agriculture, 3(4), 877-880.

Saini, M., Singh, S., Hussain, Z., Yadav, A., 2010. RAPD analysis in mungbean [Vigna radiata (L.) Wilczek]: I. Assessment of genetic diversity. Indian Journal of Biotechnology, 9(2), 137-146.

Santos, H.G., Almeida, J.A., Oliveira, J.B., Lumbreras, J.F., Anjos, L.H.C., Coelho, M.R., Jacomine, P.K.T., Cunha, T.J.F., Oliveira, V.A., 2013. Sistema Brasileiro de Classificação de Solos, terceira ed. Brasília, Embrapa, 342 p.

Santos, J.F., 2013. Resposta do feijão-caupi a diferentes densidades de plantas em Neossolo Regolítico no Agreste Paraibano. Revista Tecnologia \& Ciência Agropecuária, 7(4), 37-41.

Singh, G., Sekhon, H.S., Singh, G., Brar, J.S., Bains, T.S., Shanmugasundaram, S., 2011. Effect of plant density on the growth and yield of mungbean [Vigna radiata (L.) Wilczek] genotypes under different environments in India and Taiwan. International Journal of Agri-cultural Research, 6(7), 573-583.

Soil Survey Staff, 2014. Keys to Soil Taxonomy, twelfth ed. Washington: USDA, $362 \mathrm{p}$.

Somta, P., Prathet, P., Alisa Kongjaimun, A., Srinives, P., 2014. Dissecting quantitative trait loci for agronomic traits responding to iron deficeincy in mungbean [Vigna radiata (L.) Wilczek]. Agrivita, 36(2), 101-111.

Zhang, X., Shang, P., Qin, F., Zhou, Q., Gao, B., Huang, H., Yang, H., Shi, H., Yu, L., 2013. Chemical composition and antioxidative and anti-inflammatory properties of ten commercial mung bean samples. LWT - Food Science and Technology, 54(1), 171-178. 